\title{
"Had it too easy?" Frederik van Zyl Slabbert's resignation as leader of the official parliamentary opposition, 7 February 1986
}

\author{
F.A. Mouton*
}

\begin{abstract}
For Frederik van Zyl Slabbert, his resignation on 7 February1986 as the leader of the Progressive Federal Party and the official parliamentary opposition was a principled, self-sacrificing political statement, an act of political courage to alert whites to the harsh reality that South Africa was on the verge of a race revolution, and that parliament had entrenched apartheid and could not be used to get rid of it. This essay argues that the reality is more complex and ambiguous, and that the journalist Ken Owen's accusations that the fault did not reside with the parliamentary system, but with Slabbert himself, must be taken seriously. Owen alleged that Slabbert could deal with success, but not with defeat, because he had risen too far too fast in politics. The article concludes that Slabbert was a man of brilliant gifts, but for the leader of a small liberal party in a racist and conservative white society he lacked one crucial characteristic - tenacity - the dogged determination to keep on fighting whatever the cost.
\end{abstract}

Key words: Frederik van Zyl Slabbert; Ken Owen; Progressive Federal Party; official opposition; parliament; resignation; apartheid.

\section{Opsomming}

Vir Frederik van Zyl Slabbert was sy bedanking as die leier van die Progressiewe Federale Party en die amptelike parlementêre opposisie op 7 Februarie 1986 'n poging om blankes te waarsku dat Suid-Afrika op die rand van 'n rasse-rewolusie was; dat die parlementêre stelsel apartheid verskans het en nie gebruik kon word om daarvan ontslae te raak nie. Sy bedanking was dus ' $n$ beginselvaste en opofferende politieke handeling, 'n daad wat politieke moed geverg het. Die werklikheid is egter meer kompleks en dubbelsinnig. Die aanklag van die joernalis Ken Owen dat die probleem nie by die parlementêre stelsel berus het nie, maar by Slabbert, moet ernstig opgeneem word. Volgens Owen was dit 'n geval dat Slabbert te vinnig opgang

\footnotetext{
* F.A. Mouton is on the staff of the History Department, University of South Africa, and is currently busy with a biographical study of the leaders of the official parliamentary opposition in South Africa between 1910 and 1993.
}

\section{How to cite this article:}

F.A. Mouton, “'Had it too easy?' Frederik van Zyl Slabbert's resignation as leader of the official parliamentary opposition, 7 February 1986", Historia 60, 2, November 2015, pp 68-86. http://dx.doi.org/10.17159/2309-8392/2015/v60n2a4

\section{Copyright:}

(C) 2015. The Author(s). Published under a Creative Commons Attribution License. 
in die politiek gemaak het, en gepaardgaande daarmee nie terugslae kon verwerk nie. Hierdie artikel kom tot die slotsom dat Slabbert 'n begaafde persoon was, maar dat hy nie die nodige taaiheid (die vermoë om met 'n hardnekkig vasberadenheid aan te hou veg, ongeag die prys wat betaal moes word) om die leier van 'n klein liberale party in 'n rassistiese en konserwatiewe gemeenskap te wees, gehad het nie.

Sleutelwoorde: Frederik van Zyl Slabbert; Ken Owen; Progressiewe Federale Party; amptelike opposisie; parlement; bedanking, apartheid.

On 7 February 1986 in the House of Assembly, an emotional Frederik van Zyl Slabbert, the leader of the Progressive Federal Party (PFP), the official parliamentary opposition, explained his overwhelming feeling of absurdity in a parliament that ignored the conflict-ridden situation in the country. He described the annual noconfidence debate in the government as a "grotesque ritual in irrelevance", and that he felt "trapped in a ridiculous political debate, while outside our country is bleeding". Because he could make no contribution to getting rid of apartheid he announced his resignation from parliament. ${ }^{1}$ Slabbert was lauded by the anti-apartheid movement for his courage. Thabo Mbeki of the African National Congress (ANC) hailed him as a "new Voortrekker". ${ }^{2}$ However, in his determination to defend the principle of incremental change through parliament, and the PFP's long history of opposing apartheid, Ken Owen, a liberal journalist, ${ }^{3}$ condemned the resignation as selfindulgent and politically indefensible, "a political betrayal of epic proportions". 4 For Owen, the fault did not reside with the parliamentary system, but with Slabbert himself. He alleged that Slabbert was able to deal with success but could not handle defeat, because he had risen too far too fast in politics:

The fact is, Slabbert had it too easy. He brought no constituency with him, no political dowry except a fine mind, a handsome face and a trim figure.

According to Owen, Slabbert secured a parliamentary seat and the leadership of the predominately English-speaking liberal PFP without paying his political dues, because the party was desperate to attract Afrikaner support. In addition he had benefited from the party's eagerness, inspired by the example of President J.F. Kennedy in the United States of America, to embrace "politics of glamour" with a "pretty face, a quick tongue, a sense of style". ${ }^{5}$

\footnotetext{
${ }^{1}$ House of Assembly Debates, 7 February 1986, col. 413-431.

2 M. Gevisser, Thabo Mbeki: The Dream Deferred (Jonathan Ball Publishers, Johannesburg, 2009), p 192.

${ }^{3}$ A. Le Maitre and M. Savage, The Passion for Reason: Essays in Honour of an Afrikaner African (Jonathan Ball Publishers, Johannesburg, 2010), p 132.

${ }^{4}$ Sunday Times, 9 February 1986.

${ }^{5}$ Business Day, 13 February 1986.
} 
The attack on Slabbert created a storm of controversy, but dissipated without any in-depth debate. Owen had a reputation for irascibility, ${ }^{6}$ and even before February 1986 he expressed his criticism of Slabbert's performance as leader of the opposition, claiming that he was too understanding, too civil and too academic in his opposition to the apartheid state, ${ }^{7}$ and that this made it possible for Slabbert to reject his accusations as a hatchet job motivated by personal spite. ${ }^{8}$

Owen is also responsible that Hermann Giliomee, in his outstanding study of Slabbert in The Last Afrikaner Leaders: A Supreme Test of Power (2012) does not engage with the accusations Owen levelled at Slabbert in 1986. In his contribution to a festschrift for Slabbert, The Passion for Reason (2010), Owen explained the reasons for his attack, and conceded that it was a hatchet job (however, he did not retract his accusations), and then went on to explain why Slabbert's resignation led to his marginalisation in the new South Africa. As a result, Giliomee focuses on Owen's statements in The Passion for Reason. This allows Slabbert's narrative of his political career in his books, The Last White Parliament (1985); Tough Choices (2000); and The Other Side of History (2006) to shape the historical record. He effectively created the perception that he had never sought public office, that he accepted such duties reluctantly, and that he resigned from parliament when he realised that he could make no contribution to get rid of apartheid. He was determined not to be seen as "exhibit A for the government's sense of a democracy". ${ }^{9}$ For Slabbert, his resignation was a principled, self-sacrificing political statement, an act of political courage to alert whites to the harsh reality that South Africa was on the verge of a race revolution, and that parliament entrenched apartheid and could not be used to get rid of it. This essay argues that the reality is more complex and ambiguous and that Owen's accusations of February 1986, despite his acknowledgement of a malicious attack, must be taken seriously.

Slabbert was born in Pretoria on 2 March 1940. His parents, Barbara Hagen and Petrus Johannes Slabbert, divorced when he was two years old and from the age of seven he was raised by his paternal grandparents on a farm in the Pietersburg (Polokwane) district. He studied theology at the University of Stellenbosch with the intention of becoming a minister in the Dutch Reformed Church, but reverted to Sociology in which he secured his doctorate with an analysis of the Talcott Parsons structural-functional theories in sociology. A hallmark of Slabbert's academic and political career was his meteoric rise. At the age of 25 he was appointed a lecturer in the University of Stellenbosch's Department of Sociology. By October 1973 he was the head of the Department of Sociology at the University of the Witwatersrand (Wits). In 1974 he was elected to parliament as a candidate of the Progressive Party (PP), a small, predominately English-speaking liberal party advocating a qualified non-racial franchise. By 1979 he was the leader of the PFP, a party formed by a merging of the

\footnotetext{
${ }^{6}$ Mark Gevisser, Mail \& Guardian, June 28 to July 4 1996; Sunday Times, 22 March 2015.

${ }^{7}$ Le Maitre and Savage, The Passion for Reason, pp 39-40.

${ }^{8}$ Sunday Times, 16 February 1986.

${ }^{9}$ Sunday Times, 16 February 1986.
} 
PP and other enlightened political groups. At the age of 39 years he was the youngest ever leader of the official parliamentary opposition.

Owen's statement on Slabbert's "fine mind, handsome face and a trim figure" and his Afrikaner identity as factors in his rapid upward political mobility, is beyond doubt. Slabbert had an outstanding analytical mind and universities competed to appoint him. After he lectured at Stellenbosch between 1964 and 1968 he was appointed as a senior lecturer at Rhodes University in 1969. The next year the University of Stellenbosch head hunted him to return. In 1972 he accepted a post at the University of Cape Town (UCT), and a year later became the head of the Sociology Department at Wits although he did not apply for the post, and was appointed without an interview. ${ }^{10}$ In the process he had developed a reputation as a public intellectual with his criticism of apartheid. ${ }^{11}$ His study of the Talcott Parsons structural-functional theories convinced him that apartheid lacked legitimacy and a sustainable social order. ${ }^{12}$ By studying Karl Popper's The Open Society and its Enemies (1945) and The Poverty of Historicism (1957), as well as the works of Edmund Burke, Bertrand Russell, Isaiah Berlin and Ernest Gellner, Slabbert became steeped in the philosophy of liberalism. He developed an aversion to all closed philosophies, rejecting any form of social engineering, or final answers for political challenges. For him, apartheid and Marxism suffered from this hubris, ${ }^{13}$ and he loathed apartheid because it dehumanised those who suffered from its disadvantages, and brutalised the humanity of those who enjoyed its privileges. ${ }^{14}$

Slabbert's intelligence was complimented by his good looks. He was tall and handsome; women found him "sexy". ${ }^{15}$ In addition he had an attractive personality. Alex Boraine described the effect of his charm as falling under his spell, ${ }^{16}$ while his self-deprecatory sense of humour made him a highly likeable person. ${ }^{17} \mathrm{He}$ became popularly known as "Van". His sporting prowess was considerable. He represented Western Province in a rugby match, and played cricket for South African universities. This added to his popularity which amongst admirers bordered on the adulation of a film or a pop star. The Cape Times (3 April 1974) gushingly welcomed him into politics: "He is huge, handsome, and exudes what can only be described as a genuine South African-type charm". Even the staid The Times of London (26 September 1980) lauded him effusively: "Tall, broad and heavily handsome, Dr Slabbert appears to

\footnotetext{
10 Correspondence with D. Moodie, 25 February 2015.

11 Sunday Times, 28 February 1971.

${ }^{12}$ Le Maitre and Savage, The Passion for Reason, p 146.

${ }^{13}$ M. Shain (ed.), Opposing Voices: Liberalism and Opposition in South Africa Today (Jonathan Ball Publishers, Cape Town, 2006), pp 149-170; F. van ZylSlabbert, Tough Choices: Reflections of an Afrikaner African (Tafelberg, Cape Town, 2000), pp 35-36.

${ }^{14}$ F. van Zyl Slabbert, The Last White Parliament (Jonathan Ball Publishers, Johannesburg, 1985), p 83.

15 Interview with Kate Prinsloo, 25 September 2013.

16 Le Maitre and Savage, The Passion for Reason, p 37.

${ }^{17}$ R. Swart, Progressive Odyssey: Towards a Democratic South Africa (Human \& Rousseau, Cape Town, 1991), pp 156-157.
} 
have everything going for him ... He exudes intelligence, alertness, concern, caution and a sense of humour."

However, it was Slabbert's Afrikaner identity, combined with his enlightened political views that launched his political career. Both the United Party (UP), the official parliamentary opposition, and the PP, were desperate for high profile Afrikaner candidates to attract verligte (enlightened) Afrikaners who were concerned about the way apartheid was being implemented, and draw them away from the National Party (NP). In December 1973, the UP and the PP set out to recruit Slabbert as a parliamentary candidate for the upcoming general election. The Young Turks, a group of reformists who wanted to revitalise the UP and push it into a more enlightened direction, approached Slabbert with the offer of Randburg, a secure UP parliamentary seat. At the same time, Colin Eglin, leader of the PP, offered him the Progressive candidature for Rondebosch.

In the aftermath of the election, Slabbert always claimed that he only agreed to contest Rondebosch, a rock-solid UP fortress with mainly affluent English-speaking voters, because the PP had assured him that he could not win. The purpose of his candidature, according to Slabbert, was merely to keep the UP activists away from the Sea Point constituency which Eglin hoped to capture. And yet Slabbert secured the victory in Rondebosch. ${ }^{18}$ His charm, good looks, eloquence, and his status as a young and enlightened Afrikaner appealed to the voters. At house meetings he was introduced as "a new young Smuts and grey-haired ladies were weepy and mistyeyed". ${ }^{19}$ He certainly set the election campaign in Rondebosch alight, but it is a myth that his victory was against all expectations. Rondebosch was one of the PP's main targets because constituency delimitations were favourable for the PP and had turned it into a marginal seat. For this reason Sir De Villiers Graaff, leader of the UP and the MP for Rondebosch, moved to the safer seat of Groote Schuur. ${ }^{20}$ The PP's assessment was that it would lose the seat by 1200 votes, but Eglin, desperate for an electoral breakthrough after 14 years in the political wilderness, felt that the Progressives, with an attractive and charismatic candidate like Slabbert, could capture Rondebosch. ${ }^{21}$ Slabbert knew that Rondebosch was a winnable seat, and he was determined to win. His energetic campaign was a factor in his success, but ultimately his victory was only possible because he stood on the shoulders of Progressive activists who had been nursing the parliamentary constituencies of the Cape peninsula since 1959; it was run by a well-organised and resurgent PP under the leadership of Eglin. Rondebosch was part of an electoral breakthrough for the party, which won six parliamentary seats.

\footnotetext{
${ }^{18}$ Slabbert, The Last White Parliament, p 8; F. van Zyl Slabbert, The Other Side of History: An Anecdotal Reflection on Political Transition in South Africa (Jonathan Ball Publishers, Johannesburg, 2006), p 43; Slabbert, Tough Choices, p 37.

${ }^{19}$ Slabbert, The Last White Parliament, $\mathrm{p} 9$.

20 Progress, January 1974.

${ }^{21}$ C. Eglin, Crossing the Borders of Power: The Memoirs of Colin Eglin (Jonathan Ball Publishers, Johannesburg, 2007), p 136; Cape Times, 12 February 1986.
} 
As a member of parliament, Slabbert saw it as his mission to convince whites that without their voluntary co-operation, negotiations with the black majority and evolutionary political change would be impossible. ${ }^{22}$ With his ability to comprehend why apartheid was so attractive to Afrikaners, he could analyse the NP ideology rationally and expose the contradictions between noble sounding ideals and the brutality that was taking place in practice. ${ }^{23}$ The core of his message was that the apartheid ideal of the homelands was unobtainable and had become a threat to national security. ${ }^{24}$ After his first parliamentary session the Sunday Times (8 December 1974) praised him as one of the finest political thinkers in South Africa. So much so, that in 1978 his reputation led Eglin to appoint Slabbert as chairman of a commission to examine the party's policies, especially the principle of a qualified nonracial franchise. Slabbert's report culminated in the PFP's adoption of universal suffrage on the basis of proportional representation in a federal form of government. This political system would be based on a Bill of Rights, an independent judiciary, and the protection of minority rights through a form of consociational democracy. Thus power sharing would reconcile the need for majority rule with minority protection and the sharing of executive power between the majority and minority parties, while minorities would have a veto on crucial issues. 25

Slabbert's status as an Afrikaner PP MP made him a figure of fascination amongst Afrikaners. Prime Minister John Vorster's refusal to greet him in parliament, and the allegation by Piet Cillié, editor of Die Burger, that by visiting African countries Slabbert was condoning armed attacks against South Africa by ANC guerrillas, ${ }^{26}$ did not reflect the attitude of Afrikaners across the board. On 5 May 1974 the influential NP supporting the Afrikaans Sunday newspaper, Rapport, did the unusual by publishing a friendly and lengthy interview with Slabbert in which he was encouraged to explain his politics. Afrikaners flocked in large numbers to his public meetings. On 18 April 1974 in Stellenbosch he attracted the biggest crowd ever to attend a Progressive meeting. More than half of the audience rose to applaud him after a hard-hitting speech attacking apartheid. ${ }^{27} \mathrm{He}$ was also able to attract large and friendly Afrikaner crowds in conservative Afrikaner strongholds such as Pretoria and Pietersburg. ${ }^{28}$ Moreover, most NP MPs admired Slabbert. ${ }^{29}$ Wynand Malan, the enlightened MP for Randburg, went so far as to express his appreciation to God for the opportunity to meet Slabbert and to admire and revere him. ${ }^{30}$

\footnotetext{
22 Slabbert, The Last White Parliament, p 70.

${ }^{23}$ Le Maitre and Savage, The Passion for Reason, pp 56, 89-91.

24 Sunday Times, 19 April 1981.

${ }^{25}$ H. Giliomee, The Last Afrikaner Leaders: A Supreme Test of Power (Tafelberg, Cape Town, 2012), p 216.

${ }^{26}$ J.C. Steyn, Penvegter: Piet Cillié van Die Burger (Tafelberg, Cape Town, 2002), p 257.

27 The Argus, 19 April 1974.

${ }^{28}$ Interview with D. Moss, 24 October 2013.

${ }^{29}$ Le Maitre and Savage, The Passion for Reason, p 39.

${ }^{30}$ University of Stellenbosch (hereafter US), Frederik van Zyl Slabbert Collection (hereafter Slabbert Collection), 430.C.132, W. Malan - Slabbert, February 1986.
} 
In 1979 the PFP, desperate to attract Afrikaner support, appointed Slabbert as its leader. ${ }^{31}$ He later claimed that he had no real choice in this decision because the momentum to make him party leader began when he expressed his willingness to be considered for the position as principal of UCT. This led to prominent Progressives informing him that they wanted him to be the party leader and that they would leave the party if he turned his back on politics. He thus felt obliged to withdraw his application for the UCT post. ${ }^{32}$ However, the reality was far more complex. According to Boraine, Slabbert's closest political confidant, he was keen to succeed Eglin because he preferred leading from the front. ${ }^{33}$ Although adamant that he would not challenge Eglin, whose abrasiveness and failure to attract Afrikaner support increasingly alienated party members, Slabbert made it clear that he was available as a candidate should a leadership vacancy arise. As a result, Slabbert's admirers conducted a whispering campaign to demand a change in leadership. ${ }^{34}$ This led to the matter being raised at a Federal Executive meeting in Johannesburg on 27 July 1979 which voted by 25 votes to 19 in favour of appointing a new leader. ${ }^{35}$ Eglin resigned and recommended Slabbert as his successor. Without any effort on his part, Slabbert was appointed as party leader at a special PFP congress on 3 September 1979 in Johannesburg.

For Progressives, in the words of Ray Swart, a leading PFP MP, Slabbert was "the knight in shining armour who might yet lead the country out of the darkness into the light". ${ }^{36}$ What Slabbert's admirers did not realise was that despite his intelligence, reflected in his book South Africa's Options: Strategies for Sharing Power (1979) which he co-authored with David Welsh, he also had brilliant debating skills and was a charismatic and inspiring speaker on the public platform. ${ }^{37}$ Nevertheless, Slabbert's "shining armour" had a number of chinks. A crucial one was that his perception of himself as a reluctant politician negatively affected his attitude to parliament. In contrast to Eglin, who respected the parliamentary rituals after it took him no less than four attempts to be elected to the House of Assembly, Slabbert loathed the institution. In January 1977 he contemptuously referred to the House of Assembly as "die goor ou pot" (the rancid old pot). ${ }^{38}$ This attitude was a handicap for a party leader because as Clement Attlee, former British prime minister from 1945 to 1951 put it, a political leader should enjoy being a politician - he should have the

\footnotetext{
${ }^{31}$ Interview with D. Moss, 24 October 2013.

32 Slabbert, The Last White Parliament, pp 53, 63.

${ }^{33}$ Le Maitre and Savage, The Passion for Reason, p 39.

${ }^{34}$ Swart, Progressive Odyssey, p 155.

${ }^{35}$ University of the Witwatersrand (hereafter Wits), Progressive Federal Party Papers (hereafter PFP Papers), Ab 2.2 10, Minutes of the Federal Executive meeting, Johannesburg 27 and 28 July 1979.

${ }^{36}$ Swart, Progressive Odyssey, p 177.

37 Cape Times, 23 and 25 April 1981.

38 US, Dian Joubert Collection (unsorted), Slabbert - D. Joubert, 17 January 1977.
} 
satisfaction that his actions brought honour to himself and his friends and were of significant social value. ${ }^{39}$

Furthermore, the smooth and rapid upward mobility of Slabbert's academic and political career encouraged a lack of loyalty to state institutions and a low boredom threshold, because there was always something new and exciting awaiting him. Within two months of becoming head of the Department of Sociology at Wits he was so bored by his routine duties that he viewed his Rondebosch candidature as an escape. ${ }^{40}$ As an MP in a small party there were no avenues of political promotion. The only possibility of avoiding the drudgery of a backbencher was the leadership of the party and the official parliamentary opposition, but until 1978, Eglin seemed secure in this position. Before the 1977 general election, Prime Minister John Vorster observed that being a backbencher with limited speaking opportunities was steadily killing Slabbert politically. ${ }^{41}$ By 1978 Slabbert was so bored with what he saw as the humdrum parliamentary routine, that he informed David Welsh, a political scientist at UCT, that he wanted to return to academia. ${ }^{42}$ It was only the possibility of the party leadership that kept him in parliament. And yet, endurance was the most crucial requirement for the leader of a small liberal party in a racist and ultra-conservative society. Before 1974, Eglin had to endure defeat after defeat. Helen Suzman, the Progressives' sole MP between 1961 and 1974 was so concerned that Slabbert was not a "stayer" that she opposed his appointment as party leader. 43

Another significant chink in Slabbert's political armour was that his political career dovetailed perfectly with a golden era for the Progressives, a period of unbroken electoral growth in parliamentary, provincial and municipal elections. Slabbert had no experience in dealing with setbacks. This weakness was aggravated by the adulation of his admirers. For Slabbert, the belief held by his admirers that he could "change things" was a "kind of cultish naiveté" 44 and he did his utmost to decult his leadership. ${ }^{45}$ And yet, the excessive praise, combined with his meteoric rise, left him ill-prepared to deal with setbacks and disappointments.

In the early years of Slabbert's leadership his weaknesses were not exposed. His dedication to his duties and his uncompromising liberalism even won over Helen Suzman. In the period leading up to the 1981 general election he travelled no less that 28000 kilometres around the country, addressing up to four meetings a day, "until fatigue was a sore in the pit of my stomach". 46 Under his leadership the party

${ }^{39}$ F. Field (ed.), Attlee's Great Contemporaries: The Politics of Character (Continuum, London, 2009), p 113.

${ }^{40}$ Slabbert, The Other Side of History, p 43.

${ }^{41}$ J. D'Oliveira, Vorster - the Man (Perskor, Johannesburg, 1978), p 247.

42 Correspondence with Prof. David Welsh, 5 November 2014.

43 Wits, Helen Suzman Papers, Mb2.25.1 (File 11), H. Suzman - G. Ralfe, 10 March 1986.

44 US, Slabbert Collection, 430.X, Unpublished memorandum (August 1986) by Slabbert on the reasons why he resigned as party leader, $\mathrm{p} 4$.

45 Sunday Times, 16 September 1979 and 9 February 1986.

${ }^{46}$ Slabbert, The Last White Parliament, p 70. 
campaigned with great energy and enthusiasm that apartheid was a failed ideology and that the only political solution was a national convention to which the imprisoned Nelson Mandela, leader of the ANC, should be invited. Slabbert was also in the fortunate position that he inherited a well organised and confident party from Eglin, while the NP was in a vulnerable position with the exposure of the misuse of public funds in the Information Scandal. Many enlightened voters were not only disgusted by the exposure of corruption in the ruling party, but were also uncomfortable with the public image of P.W. Botha, who had succeeded Vorster as prime minister in 1978. Botha was an unsophisticated political bruiser whose finger wagging abusiveness led to him being nicknamed the "groot krokodil" (big crocodile). In addition, the presence of the ultra-conservative A.P. Treurnicht in the NP meant that some verligtes were willing to support the PFP. On 7 November 1978 the PFP won Edenvale from the NP in a by-election. ${ }^{47}$ Furthermore, the party contested the 1981 general election under favourable circumstances. The NP had to defend a number of seats it had won in the 1977 general election as a result of the opposition vote being divided between the New Republic Party (NRP), a rump of the UP, and the PFP. With the NRP a spent force in 1981, the PFP improved its share of the popular vote to $19.09 \%$ compared to the $16.71 \%$ in 1977 , and increased its parliamentary representation from 18 to 26 seats. In the PFP, as well as the English-medium press, the credit for the party's gains was given to Slabbert. 48

Slabbert's optimism of continued electoral growth for the PFP was fuelled by the founding of the right-wing Conservative Party (CP) on 20 March 1982. Botha drove Treurnicht and his followers out of the NP when they opposed his attempts to adapt apartheid to a changing world. Slabbert was convinced that this split in the Afrikaner vote created an opportunity for the PFP to win at least 45 seats in a general election. Such a result, combined with the seats won by the CP, would lead to a hung parliament, securing the Progressives the balance of power in the House of Assembly. This situation, it was hoped, would force the leadership of the NP, under increasing international pressure, to choose the path of reform. ${ }^{49}$ However, nothing came of these high hopes because the founding of the CP led to the marginalisation of the PFP. Botha's reforms, the opening of social amenities to blacks, the abolition of white job protection and a programme of improvement in black townships, ${ }^{50}$ fuelled not just the rise of the rise of the $\mathrm{CP}$, but also of the neo-fascist Afrikaner Weerstandsbeweging (AWB) under the leadership of the thuggish Eugene Terre'blanche. Enlightened voters, including a significant number of PFP supporters, felt that as Botha was doing its best with reforms they had to vote NP to support him against the reactionary $\mathrm{CP}$ and $\mathrm{AWB}$. The NP adroitly exploited the fear of the rightwing to win over the electoral base of the PFP. A cabinet minister laughingly told Slabbert:

\footnotetext{
47 Beeld, 8 November 1979.

48 Sunday Times, 3 May 1981; The Cape Times, 2 May 1981.

${ }^{49}$ US, Slabbert Collection, 430.E 2, "The Balance of Power Strategy in White Politics, 12 October 1982", Draft of an article for the Sunday Tribune.

${ }^{50}$ B. Pottinger, The Imperial Presidency: PW Botha, the First Ten Years (Southern Book Publishers, Johannesburg, 1988), p 196.
} 
Come election time all we do is show Eugene Terblanche giving his Nazi salute on TV and your voters will flock to our tables in the northern suburbs of Johannesburg. 51

Botha, eager to neutralise Slabbert's criticism and attraction to voters, furthermore initiated a campaign to condemn Slabbert as someone who boycotted orderly reform to secure white survival. This process began in 1980 when Botha abolished the Senate and replaced it with a nominated President's Council, consisting of white, coloured and Indian members, to investigate and advise the government on constitutional reforms. ${ }^{52}$ However, Botha made it clear that these reforms could never include the principle of a one-man-one-vote election for a single parliamentary chamber. For his part, Slabbert was adamant that the PFP would not be "hijacked for apartheid" and refused to be drawn into a process of constitutional reform that fell short of the political aspirations of the black majority. With the support of the parliamentary caucus he decided to boycott the President's Council. 53 This led to the PFP being labelled as a party that "boycotted reform" by the NP and the Afrikaansmedium press. ${ }^{54}$ It was a perception that convinced most enlightened Afrikaners to retain their faith in the NP despite all its shortcomings. This contributed to the PFP attracting only about 5\% of the Afrikaner vote in the 1981 general election. ${ }^{55}$ The perception that Slabbert was an obstacle to reform intensified with the founding of the CP. ${ }^{56}$ Fred Mouton and Orin Scott, respectively cartoonists of Die Burger and Beeld, regularly portrayed Slabbert as sabotaging reform in the company of Treurnicht and an AWB thug. 57

The effectiveness of the NP's claim that Slabbert played into the hands of the $\mathrm{CP}$ and AWB by opposing Botha's reforms, was evident in the Waterkloof by-election of 10 May 1983. With an electorate consisting of affluent businessmen, high-level civil servants and academics from the Universities of Pretoria and South Africa, the PFP did exceptionally well in this constituency in the 1981 election. In the 1982 municipal election, Waterkloof elected two Progressive city councillors. While the NP focused on the rural by-elections in Soutpansberg and Waterberg on the same day in an attempt to smash the CP, the PFP threw its entire national organisation, with no expenses

\footnotetext{
51 Slabbert, The Last White Parliament, p 157.

${ }^{52} \mathrm{R}$ Schrire (ed.), Leadership in the Apartheid State: From Malan to De Klerk (Oxford University Press, Cape Town, 1994), p 181.

53 Sunday Times, 8 June 1980.

54 Slabbert, The Last White Parliament, p 69.

${ }^{55}$ H. Giliomee, “Demokratiese Party se Werklike Rol”, Die Suid-Afrikaan, June/July 1988, p 7.

56 See for example the Beeld, 2 November 1982, 7 and 11 May 1983; Die Burger, 2, 3 and 5 November 1982; and Die Transvaler, 28 April 1983.

57 Beeld, 10 May and 29 October 1983; and Die Burger, 27 November 1984.
} 
spared, into the contest. ${ }^{58}$ And yet, the NP increased its majority because a number of Progressives, determined to counter the CP, voted for the NP. 59

Slabbert took the Waterkloof defeat well because he felt that the NP's 1981 majority was just too big to be erased. 60 However, he was not as sanguine with the result of the 1983 referendum with its "Yes/No" options to the question: "Are you in favour of the implementation of the Constitution Act, 1983, as approved by Parliament?"61 The new constitution proposed to share power with the coloureds and Indians in a tricameral parliament with an inbuilt majority for whites and a powerful executive president. Slabbert's stance was that the proposed constitution was simply a cover-up, a confidence trick that safeguarded apartheid; he maintained that it would polarise whites and blacks, promoting conflict and widespread dissatisfaction. ${ }^{62}$

Botha's response was simple but effective - that he could not continue with reform if there was a "No" vote in the referendum. ${ }^{63}$ The NP had the full support of the Afrikaans-medium press, and the state controlled South African Broadcasting Corporation (SABC) which gave the NP nearly $400 \%$ more airtime than the PFP, 64 while the English-medium press, which usually supported the Progressive view, was deeply divided on the vote. The Sunday Times, The Natal Mercury, the Daily Dispatch, The Friend, Finance Week and the Financial Mail urged a "Yes" vote, while The Star advised its readers to abstain. Furthermore, the PFP lacked the financial means for an effective campaign. The NP, supported by big business, spent more money on fullpage advertisements in the Sunday press on one day than the PFP could spend on the entire campaign. ${ }^{65}$ As he had done in the 1981 election, Slabbert gave his all, but despite his best efforts the proposed constitution was accepted with an overwhelming majority of $66 \%$ to the $34 \%$ of "No" votes, of which about $10 \%$ were liberal protest votes. ${ }^{66}$ Tens of thousands of traditional Progressive supporters, up to $30 \%$ of them, ignored Slabbert and voted "Yes" because they saw the new constitution as a step in the right direction. ${ }^{67}$ During the referendum campaign Slabbert became deeply depressed about his inability to convey to whites his fear for the future of the country. ${ }^{68} \mathrm{He}$ took the result as a personal blow, finding it difficult to

\footnotetext{
58 Correspondence with Douglas Gibson, 30 October 2014.

${ }^{59}$ Wits, PFP Papers, Ab 2.2.9, D. Moss, "Report on Waterkloof By-election Campaign', May 1983.

${ }^{60}$ Correspondence with D. Moss, 14 July 2014.

${ }^{61}$ E. McKenzie, "The 1983 Referendum: The English Press and the Progressive Federal Party Campaign", Kleio, 23, 1991, pp 85-96.

62 The Star, 1 November 1983; Rand Daily Mail, 1 November 1983.

${ }^{63}$ Rand Daily Mail, 28 November 1983.

${ }^{64}$ Rand Daily Mail, 1 November 1983.

65 Slabbert, The Last White Parliament, p 112.

${ }^{66}$ The Star, 2 November 1983.

${ }^{67}$ Sunday Times, 6 November 2014.

68 Swart, Progressive Odyssey, p 165.
} 
accept "that intelligent, successful people can collectively abandon reason and common sense". 69

The referendum was the first serious setback in Slabbert's political career and his immediate reaction was to leave parliament. ${ }^{70}$ Although Suzman and Eglin managed to make him change his mind, his despondence and reluctance to remain in parliament was an ominous sign for the PFP. It was in dire need of strong and dynamic leadership after the Waterkloof defeat and the referendum result. These defeats left the Progressives in Pretoria, for example, so demoralised that it was difficult to get members to attend party meetings, or to do the necessary canvassing. ${ }^{71}$ Party morale took a further battering with the by-election defeat in the Port Elizabeth constituency of Newton Park on 1 May 1985. The PFP had failed by a meagre 1195 votes to capture the constituency from the NP in the 1981 general election, but in 1985 the seat seemed right for the plucking. Botha's reform process had stalled; the Eastern Cape was in the grip of black unrest; a stagnant economy meant significant white unemployment in the constituency; and the CP entered a candidate who had no chance of winning but would attract votes from the NP. Even the NP anticipated defeat, but on polling day the PFP's support dropped to a disappointing $35.5 \%$ compared to the $44.1 \%$ in $1981 .^{72}$ For Slabbert, it was a devastating blow, making it clear that the PFP's stance on the necessity to negotiate with the ANC, and the party's exposure of police brutality, had alienated white voters because the party was seen as only caring about blacks. ${ }^{73}$ It was clear that nothing would come of the PFP ideal of securing the balance of power in parliament.

At the same time, Slabbert also had to endure the contempt of the antiapartheid movement. Botha's reforms unleashed pent-up forces which could not be regulated from above. They not only failed to satisfy black aspirations, but raised frustrated expectations. This led to the growth of a revolutionary climate and an ever increasing cycle of violence which the apartheid state could not break. Despite increasing brutality by the security forces the apartheid state lost control of numerous black townships. On a personal level, Slabbert himself was a victim of violence. His home was damaged by an unexplained fire in 1981 and on several occasions the tyres of his car were slashed. ${ }^{74}$ In this atmosphere of violence black leaders questioned the bona fides of liberal politicians, accusing the PFP of being the "icing sugar on the system of oppression" or of keeping up the "illusion of peaceful change". ${ }^{75}$ After 1983, the PFP came under increasing pressure from the United

${ }^{69}$ Slabbert, The Last White Parliament, p 113.

70 Slabbert, Tough Choices, p 45.

71. Wits, PFP Papers, Ab 2.2.9, C. Gilfillan - A. Boraine, 22 July 1984.

72. Die Burger, 25 May 1985, Beeld, 1 May 1985.

73. US, Slabbert Collection, 430.X1, Unpublished memorandum (August 1986) by Slabbert on the reasons why he resigned as party leader, $\mathrm{p} 8$.

74. Slabbert, Tough Choices, pp 43-44.

75. University of the Free State (hereafter UFS), Archive for Contemporary Affairs (hereafter ACA), P.W. Botha Collection, File PS3/1/2, Frederik van ZylSlabbert, "Problems of a Parliamentary Opposition in South Africa", Paper delivered at a symposium in Bonn, Germany, May 1981, p 7. 
Democratic Front (UDF) that was formed in 1983 to oppose the tricameral parliament. The accusation was made that because it had a presence in parliament, the PFP provided the apartheid state with legitimacy.

The ANC's contempt for the PFP was highlighted in 1985 when Slabbert attempted to create a National Convention Movement. The idea was to form a pressure group by bringing together at a national convention all parties and organisations who supported negotiations between the ANC and the apartheid state. Initially, prominent anti-apartheid leaders such as Allan Boesak and Desmond Tutu were supportive, but when the ANC claimed that the initiative would undermine the people's struggle and alleged that Slabbert was seeking a common cause with Botha, the plan imploded. ${ }^{76}$ That he was not seen as part of the anti-apartheid struggle by the ANC leadership, whom he met in Lusaka in October 1985, was a chastening experience for Slabbert, ${ }^{77}$ especially in the light of the fact that the calibre of the ANC leadership impressed him greatly. He was particularly taken by the charming Thabo Mbeki who was keen that Slabbert, should leave parliament. ${ }^{78}$ Mark Gevisser, Mbeki's biographer, refers to the meeting as a "seduction" of Slabbert. ${ }^{79}$

The meeting with the ANC leadership brought home to Slabbert how out of touch parliament was with what was happening in South Africa. ${ }^{80}$ He was horrified that with the country on the verge of a bloody race revolution, the average NP MP was ignorant of developments outside of parliament. But even more disturbing were the careerists in the NP who knew that apartheid was impractical and immoral, but continued to support it. ${ }^{81}$ Slabbert found it increasingly difficult to deal with the frustration that enlightened Afrikaners agreed with what he said on the necessity of reform, and then proceeded to vote for the $\mathrm{NP}, 82$ especially as his image as a glamorous young leader was fading. Slabbert's inability to live up to the high hopes invested in him in 1979 was regularly highlighted by Fred Mouton in his cartoons for Die Burger. He portrayed Slabbert in a fraying superman suit as the ropey and blundering "Supervan". This image was the result of a statement made by Zach de Beer, a prominent PFP member, that to be the leader of the opposition in South Africa

\footnotetext{
${ }^{76}$ US, Slabbert Collection, 430.X1, Unpublished memorandum (August 1986) by Slabbert on the reasons why he resigned as party leader, p 8; Weekly Mail, 8-14 November 1985.

77 Slabbert, Tough Choices, p 103; J. Butler, R. Elphick and D. Welsh (eds), Democratic Liberalism in South Africa: Its History and Prospect (Wesleyan University Press, Cape Town, 1987), p 403.

${ }^{78}$ A. Boraine, What's Gone Wrong? On the Brink of a Failed State (Jonathan Ball Publishers, Johannesburg and Cape Town, 2014), p 34.

${ }^{79}$ Gevisser, Thabo Mbeki, p 192; R.W. Johnson claims that Mbeki charmed Slabbert into resigning from parliament by creating the expectation that he would have the privilege of leading Afrikaner groups to meet with the ANC in exile. Giliomee rejects this in The Last Afrikaner Leaders (pp 225-226) and argues convincingly that Slabbert was not a person who would allow himself to be manipulated and used by Mbeki.

${ }^{80}$ Slabbert, The Other Side of History, p 46.

${ }^{81}$ Slabbert, The Last White Parliament, p 155.

82 US, Slabbert Collection, 430.01, Transcript of David Welsh's interview with Slabbert, 1985.
} 
one had to be a superman.83 On 29 October 1985 Mouton produced a cartoon of a gloomy looking "Supervan" selling his recently released memoirs, The Last White Parliament, to a sceptical looking customer, with the statement that he had written the book because his best years were behind him.

The next day, Slabbert had every reason to be gloomy because the PFP suffered heavy defeats in the Port Natal and Springs by-elections. In Springs the party's total number of votes dropped to a paltry $14 \%$ compared to the $36 \%$ in 1981 , because Progressives voted for the NP candidate to keep the CP out. In the Port Natal constituency, where The Natal Mercury had urged Progressives to vote for the NP to support Botha's reforms against the right, the PFP candidate came a distant second. 84 On the same day, the ultra-conservative Herstigte Nasionale Party, in an election agreement with the CP, took Sasolburg from the NP, while the CP drastically reduced the NP's majorities in the Vryburg and Bethlehem by-elections.

These by-election results were an indication that the PFP would lose its status as the official parliamentary opposition to the CP in the next general election. ${ }^{85}$ The prospect must have filled Slabbert with horror because he made it clear in The Last White Parliament that after his years as a backbencher he knew exactly what he did not want. ${ }^{86}$ In the aftermath of the disappointing by-election results Slabbert, accompanied by Eglin, went on a study tour to Australia and New Zealand. During their travels he confided in Eglin that he was considering resigning his seat and position as party leader because he felt as if he was wasting his time in parliament. He was convinced that the political situation in the country had reached a stalemate between the politics of repression and the politics of revolt, leaving the PFP MPs as mere spectators. Eglin, in his attempt to persuade Slabbert to remain in parliament, urged him to meet with P.W. Botha to discuss his concerns. ${ }^{87}$

Slabbert met Botha on 25 November in his office in the Union Buildings, Pretoria. Determined to convince the president of the necessity to bring about fundamental reform, Slabbert avoided a confrontation by being deferential. However, he still made it clear that a bold initiative was needed to break the deadlock in the country and urged not only the unconditional release of Mandela and the lifting of the ban on the ANC, but the need to begin negotiations with the ANC leadership. Botha countered that in his view it was a reasonable request that Mandela should first renounce violence before there could be talk of his release. Furthermore, Botha was adamant that he would not give up the right of whites to self-determination, and that he would not destroy the 1983 constitution to create a new one. The meeting ended on a cordial note, with the notoriously cantankerous Botha doing his utmost to be

83 W.D. Beukes (ed.), Oor Grense Heen: Op Pad na 'n Nasionale Pers 1948-1990 (Nasionale Boekhandel, Cape Town, 1992), p 145.

${ }^{84}$ Beeld, 31 October 1985; The Natal Mercury, 29 October 1985.

85 Die Burger, 1 November 1985.

${ }^{86}$ Slabbert, The Last White Parliament, p 53.

${ }^{87}$ Slabbert, The Other Side of History, p 45. 
amiable and reasonable. ${ }^{88}$ Slabbert would later claim that the realisation that he had failed to convince Botha of the necessity of a bold initiative, combined with the president's statement that he was confident he had the support of the majority of blacks, left him with a "pervasive sense of despair and helplessness". ${ }^{89}$

According to Slabbert, the turn of events that finally dispelled any misgivings about leaving parliament was the exposure of the apartheid state's systematic violation of the Nkomati Accord. In terms of this agreement, signed between the governments of South Africa and Mozambique on 16 March 1984, the apartheid state undertook to stop arming the Renamo rebel movement, but by 1986, rumours were surfacing that in contravention of the agreement, the South African government had continued to provide Renamo with military assistance. In September 1985, Slabbert in his capacity as leader of the opposition, was assured by cabinet ministers and the head of the South African Defence Force, that South Africa had kept its part of the bargain. However, rumours persisted and on 3 January 1986, Slabbert went to Mozambique to visit Samora Machel and the president provided him with documentary proof that South Africa was still actively supporting Renamo. This left Slabbert feeling abused and manipulated by the apartheid state. He wrote:

The whole ritual of loyal opposition, honouring the House, consulting the Leader of the Opposition was so much hogwash. It was a constitutional charade which they indulged in to suit their purposes. They had no compunction to lie, misinform or disinform parliament and any member associated with it, if they thought it necessary. ${ }^{90}$

For Slabbert, his meeting with Botha and the exposure of the apartheid state's continued support of Renamo, convinced him that desperate measures were necessary to end the political stalemate in South Africa. Against this background, in December 1985 he drew up a new parliamentary strategy for the PFP. This document, entitled "A possible strategy to apply constitutional leverage towards a non-racialdemocracy", recommended that Progressive MPs resign their seats, contest the subsequent by-elections and that those who were re-elected should refuse to return to parliament unless Botha scrapped the Population Registration Act and restored freedom of choice on racial and ethnic grounds. ${ }^{91}$ Eglin was aghast and filled with despair and disbelief that Slabbert could have produced such a "flawed and fanciful scheme" and rejected the proposed strategy outright, saying he felt it would achieve nothing of value. ${ }^{92}$

\footnotetext{
${ }^{88}$ Die Burger, 19 February 1986.

${ }^{89}$ US, Slabbert Collection, 430.X1, Unpublished memorandum (August 1986) by Slabbert on the reasons why he resigned as party leader, $\mathrm{p} 17$.

${ }^{90}$ US, Slabbert Collection, 430.X1, Unpublished memorandum (August 1986) by Slabbert on the reasons why he resigned as party leader, $\mathrm{p} 26$.

${ }^{91}$ Slabbert, The Other Side of History, pp 62-74.

92 Eglin, Crossing the Borders of Power, p 216.
} 
Eglin's despair and disbelief was understandable because by 1986 there was a growing element in the NP that had accepted the inevitability of majority black rule and felt that Mandela should be released; the ANC unbanned; and that direct negotiations with the liberation movement should take place. ${ }^{93}$ Furthermore, in Eglin's view, parliament as a means to oppose apartheid was just as relevant as it had been in 1974 when Slabbert entered politics; he was convinced that it could be used to expose the atrocities of the apartheid state. ${ }^{94}$ Eglin felt that parliament remained an important platform to expose the horrors of apartheid; to assist its victims; to convince whites to negotiate with the liberation movements; and to defend the values necessary for an open, humane society. All this, he argued, the PFP was doing with gusto. In The Last White Parliament, Slabbert pledged his part in this defence, saying "Protest has to be kept alive, and I cannot expect others to do it if I am not prepared to do it myself". 95 These were not mere hollow words, because on 16 October 1985, Slabbert addressed a large crowd of about 1250 PFP supporters who packed the Johannesburg City Hall to launch the "Van Zyl Slabbert Trust", a drive to collect R10 million to fund the party's campaign in the next general election. ${ }^{96}$ Furthermore, in an interview with the Financial Mail (1 November 1985), he reiterated his faith in parliamentary politics:

It seems particularly futile to rant and rave and write interesting papers, lead protest marches and so on. I don't doubt the validity of that, but I never saw myself in that kind of role. I still feel that a good, hard engagement with a Cabinet Minister is worth more than howling at the moon at an English-speaking campus.

And yet, by December 1985, Slabbert had convinced himself that constitutional change towards a non-racial democracy was impossible in a parliament dominated by the NP:

This [constitutional change] can only be done in effect by totally demolishing the existing Parliament and creating an entirely new one, and it seems to me highly unlikely that the prime beneficiaries of the system can of their own violation be the major agents of change. 97

Botha's intransigence and the deceit surrounding the support for Renamo, undoubtedly encouraged despondency, but did not warrant Slabbert's loss of faith in parliamentary politics. It can be argued that he exaggerated the importance of these events to provide himself with the moral high ground to justify his resignation. This was Botha's view, leading to his release of the transcript of their 25 November 1985 meeting to show how cordial it had been. John MacLennan, political correspondent of the Sunday Tribune, on reading the transcript concluded that Slabbert "came across in

\footnotetext{
93 Frontline, March 1986, pp 35-37.

94 Slabbert, Tough Choices, p 99.

95 Slabbert, The Last White Parliament, pp 54, 70.

96 The Citizen, 17 October 1985.

97 US, Slabbert Collection, File 430.C. 160, Slabbert - H. Oppenheimer, 14 March 1986.
} 
the interview like a schoolboy talking to his favourite uncle". 98 Ultimately the crucial factor for Slabbert's resignation resides in the fact that with his "fine mind, handsome face and trim figure" success and achievements came too easily, leaving him unable to cope with adversity and defeat. In The Last White Parliament, Slabbert described the position of the leader of the opposition in the following terms:

... you needed iron in the soul not to lose faith in what you believed or lose sight of your objectives. You had to keep plugging away patiently without the prospect of reward and always be prepared for failure and disappointment. 99

Because Slabbert had it too easy, not earning his political spurs in the rough and tumble of parliamentary politics, he lacked the necessary "iron in the soul" to deal with defeats such as the 1983 referendum and the setbacks at Newton Park and Springs. As a result he lost all hope that parliament could be used to end apartheid. ${ }^{100}$ Slabbert, with Eglin's rejection of his strategy for the PFP fresh in his mind, decided to resign from parliament at the conclusion of the no-confidence debate in February. ${ }^{101}$ Although Eglin and other senior PFP members were kept in the dark, Slabbert informed Mbeki of his intentions. Mbeki responded in a letter which Slabbert, according to Boraine's recollection, received on the day he resigned from parliament. Mbeki expressed his support for Slabbert and urged him to reiterate that the apartheid system could not be reformed - it had to be replaced. ${ }^{102}$

Slabbert only told Eglin early on the morning of Friday 7 February 1986 that he would announce his retirement from parliament later that same day. Eglin, who thought that he had talked Slabbert out of taking this drastic step, was stunned. The PFP parliamentary caucus was only informed of Slabbert's intention some 45 minutes before he made his resignation speech. The caucus was left in amazement and despair. ${ }^{103}$ For Slabbert, his departure from parliament was one of "the most liberating experiences of my life". ${ }^{104}$ This sense of freedom came at the cost of the PFP, the only parliamentary party to campaign for negotiations with the ANC and to oppose white domination. The news of Slabbert's resignation left Progressive activists shattered. David Gevisser informed Slabbert:

When I heard the news last week, it came almost like a physical blow. I had literally to sit down to stop myself from being ill. ${ }^{105}$

The Progressives felt betrayed. As Suzman explained to Slabbert:

\footnotetext{
${ }^{98}$ Sunday Tribune, 23 February 1986.

${ }^{99}$ Slabbert, The Last White Parliament, p 42.

100 Weekly Mail, 28 February - 6 March 1986.

${ }^{101}$ A Boraine, A Life in Transition (Zebra Press, Cape Town, 2008), p 128.

102 US, Slabbert Collection, 430.C.139, Thabo Mbeki - Slabbert, January 1986; Boraine, What's

Gone Wrong, pp 36-37.

103 Correspondence with Peter Soal, 6, 8 November and 8 December 2014.

104 Slabbert, Tough Choices, p 51.

105 US, Slabbert Collection, 430.C.71, D. Gevisser - Slabbert, 11 February 1986.
} 
The point is you made a commitment - not for life - but certainly for the next three years, and you have walked away from it, so casually that it was breathtaking. You have made the task of those of us who have stayed "to engage the system", that much more difficult. 106

It was against this background that Owen launched his scathing attack on Slabbert in the Sunday Times of 9 February 1986.

Slabbert's resignation was a fatal blow for the PFP. As Suzman puts it in her memoirs - who wants to vote or work for a party in which the leader declared parliament irrelevant. ${ }^{107}$ The perception created by the resignation was that the Progressives were simply wasting their time in parliament. This contributed to the party's poor performance in the 1987 general election, when it lost its status as the official parliamentary opposition to the CP. In 1989, the demoralised PFP merged with two smaller parties to form the Democratic Party (DP). By then Slabbert was internationally lauded for his role in the activities of the Institute for a Democratic Alternative for South Africa (IDASA) which he and Boraine had formed in 1987. The aim of the Institute was to create forums where people could engage in debate, discussion and common projects which focused on democratic values and alternatives to the present political, social and economic order in South Africa. IDASA did good work in encouraging the principle of negotiations with the ANC amongst the Afrikaner elite, but by leaving parliament Slabbert had turned his back on the difficult task of convincing fearful and conservative white voters at grassroots level of the necessity to bring about political reform.

The challenge to deal with conservative voters in the hustings was left to the politicians of the PFP/DP and after 1989, to F.W. de Klerk, a member of the Botha cabinet, who was profoundly influenced by his experience of the tricameral parliament. Although Slabbert loathed the tricameral parliament he had to concede that it encouraged a multiracial bonhomie and tolerance in an institution where previously very little had existed. ${ }^{108}$ This in its own right was an important breakthrough because NP MPs encountered the victims of apartheid for the first time. During parliamentary debates, listening to others recounting incidents of racial humiliation; forced removals and detention without trial, was traumatic for NP MPs and in the longer term this helped to convince them, especially De Klerk, that dramatic change had to be implemented. ${ }^{109}$ In Botha's cabinet there was a growing impatience with him and the slow pace of the reform process. Eventually his ministers forced Botha to resign in 1989 and he was replaced by De Klerk who, in the face of growing violence, accepted that the costs had become too high to maintain the apartheid state. On 2 February 1990, De Klerk announced in parliament that the ANC

106 US, Slabbert Collection, 430.C.226, Suzman - Slabbert, 9 March 1986.

107 H. Suzman, In No Uncertain Terms (Jonathan Ball Publishers, Johannesburg, 1993), p 255.

108 Slabbert, The Last White Parliament, p 160.

${ }^{109}$ F.W. de Klerk, The Last Trek - a New Beginning: The Autobiography (Macmillan, London, 1998), p 96. 
was to be unbanned and that political prisoners would be released. ${ }^{110}$ Contrary to Slabbert's pessimistic outlook, fundamental change was accelerated in the aftermath of the tricameral parliament. However, now without a political power base, in 1990 Slabbert became a mere observer of the negotiation process that was initiated to create the new South Africa and the introduction of the new political dispensation after 1994.

Slabbert died of a liver ailment on 14 May 2010. He was a man of brilliant gifts, a sharp intellect, great oratorical ability, a telegenic and charming politician with a warm and magnetic personality. Between 1974 and 1986 he helped to destroy the moral legitimacy of apartheid by exposing its cruelties in parliament, but for the leader of a small liberal party in a racist and conservative white society he lacked one crucial characteristic - tenacity - the dogged determination to keep on fighting whatever the costs. It was a flaw that would be fatal for the PFP, and for Slabbert's public career.

${ }^{110}$ D. Welsh, The Rise and Fall of Apartheid (Jonathan Ball Publishers, Jeppestown, 2009), pp 266, 359. 